\title{
Mass mortality of giant abalone Haliotis gigantea caused by a Francisella sp. bacterium
}

\author{
Takashi Kamaishi ${ }^{1, *}$, Satoshi Miwa ${ }^{2}$, Etsuro Goto ${ }^{3}$, Tomomasa Matsuyama ${ }^{1}$, \\ Norihisa Oseko' ${ }^{1,4}$ \\ ${ }^{1}$ National Research Institute of Aquaculture, Minami-Ise, Mie 516-0193, Japan \\ ${ }^{2}$ Inland Station, National Research Institute of Aquaculture, Fisheries Research Agency, Tamaki, Mie 519-0423, Japan \\ ${ }^{3}$ Shimane Prefectural Fisheries Technology Center, Inland Water Fisheries and Coastal Fisheries Division, Kashima, \\ Shimane 690-0322, Japan \\ ${ }^{4}$ Present address: Diagnosis and Training Center for Cold-water Fish Diseases, Toyohira, Sapporo 062-0922, Japan
}

\begin{abstract}
In February 2005, a mass mortality of giant abalone Haliotis (Nordotis) gigantea Gmelin, 1791 occurred on a private abalone farm in Shimane Prefecture, Japan. The cumulative mortality rate reached about $84 \%$. In histological observations, bacteria-like spherical particles were found in affected animals, suggesting a bacterial infection. Many of the bacteria-like particles were found in the cells that were presumably host phagocytes. DNA was extracted from the hemolymph of a diseased abalone and a bacterial 16S rRNA gene was amplified by PCR. The bacterium was classified within the genus Francisella by gene sequence analysis. A bacterial isolate was obtained by spreading hemolymph of a diseased abalone on modified Eugon agar dissolved in $70 \%$ seawater containing $1 \%(\mathrm{w} / \mathrm{v})$ hemoglobin. A gene fragment of the expected size was amplified from the bacterial isolate by PCR using specific primers for the 16S rRNA gene obtained from the diseased abalone. Experimental infections were carried out by intramuscular injection with the bacterial isolate or by immersion in the bacterial suspension using 2 species of abalone, the giant abalone and the Japanese black abalone Haliotis (Nordotis) discus discus Reeve, 1846. Most (98.6\%) of the abalone challenged with the bacterial isolate died in experimental infections. These results suggest that the Francisella sp. isolate was the causative agent for the mass mortality of giant abalone. This is the first report of a pathogenic Francisella sp. isolate for mollusks.
\end{abstract}

KEY WORDS: Haliotis gigantea · Giant abalone · Francisella spp. · Mass mortality

\section{INTRODUCTION}

In February 2005, a mass mortality of unknown etiology occurred in cultured giant abalone Haliotis (Nordotis) gigantea Gmelin (Japanese common name: megai-awabi) on a private abalone farm in Shimane Prefecture, Japan. Moribund abalone came out of their shelters in the daytime despite their nocturnal habit and congregated in the vicinity of the water surface on the side wall of the rearing tanks. The adhesive strength of the abalone was decreased and affected abalone often lay upside down on the bottom of the tanks and eventually died. There were no notable clinical signs, including those for amyotrophia, in dead abalone. Amyotrophia has been the most serious problem in abalone hatcheries in western Japan (Nakatsugawa 1990, Momoyama et al. 1999). Moribund abalone suffering amyotrophia show atrophy of foot muscle and sometimes exhibit a few incisions on the front margin of the shells. Although amyotrophia has been observed in $H$. discus discus, $H$. discus hannai, and $H$. madaka, the occurrence of the disease has not been reported in the giant abalone (Momoyama et al. 1999).

For the total of 6000 abalone initially cultured on the farm in Shimane Prefecture, cumulative mortality reached $84 \%$ by the end of June, when mortality finally ceased. Abalone health did not improve with 
various efforts such as changing the method of bottom cleaning, transferring the shells to cages, increasing water temperature, or freshwater bathing. The mortality started at relatively low temperatures, about $12^{\circ} \mathrm{C}$, and continued until about $18^{\circ} \mathrm{C}$. No bacterium was isolated using general culture media. Mortality was also seen when normal giant abalone were put into a tank in which many abalone had died. Therefore, an infectious agent was suspected as the cause of the mortality.

The aim of the present study was to identify the causative agent of mass mortality among Haliotis gigantea on a private abalone farm in Shimane Prefecture in February 2005.

\section{MATERIALS AND METHODS}

Preliminary experiment. Moribund giant abalone Haliotis (Nordotis) gigantea Gmelin, 1791 (4 yr old, average shell length: $80 \mathrm{~mm}$ ) were sent to the NRIA from an aquaculture farm in Shimane Prefecture. The hemolymph from 2 moribund abalone was inoculated on either brain heart infusion agar, heart infusion agar (containing $2 \% \mathrm{NaCl}$ ), thiosulfate citrate bile saccharose agar, Marine Agar 2216, or Eugon agar with 1\% (w/v) hemoglobin (Kamaishi et al. 2005). The culture media were incubated at $15^{\circ} \mathrm{C}$ for $1 \mathrm{wk}$.

Healthy giant abalone (average shell length: $70 \mathrm{~mm}$ ) were sent to the NRIA from Shimane Prefectural Fisheries Technology Center. Three groups $(\mathrm{n}=10$ group $^{-1}$ ) of healthy abalone were injected intramuscularly with either $0.05 \mathrm{ml}$ of pooled hemolymph from the 2 moribund abalone, $0.05 \mathrm{ml}$ of muscle homogenate filtered through a $0.45 \mu \mathrm{m}$ membrane, or phosphatebuffered saline (PBS) as a control. The muscle homogenate was prepared by homogenizing muscle tissue from the 2 moribund abalone with PBS (the volume ratio of the tissue and PBS was $~ 1: 10$ ). The abalone were reared at $13^{\circ} \mathrm{C}$, which is close to the water temperature when the mass mortality started.

Animals. Moribund giant abalone (4 yr old, average shell length: $80 \mathrm{~mm}$ ) were collected in March 2005 from the abalone farm where the mass mortality occurred. They were transferred to the NRIA, and processed for histopathology, 16S rRNA PCR, and bacterial isolation.

Histology. Various parts of the body were excised from 6 seemingly diseased abalone and fixed in Davidson's solution (Bell \& Lightner 1988). The fixed tissues were routinely embedded in paraffin. Two sets of sections ( $3 \mu \mathrm{m}$ thick) were prepared from each paraffin block. Sections were made transversely except for the gill, which was sectioned parallel to the organ's longitudinal axis. They were stained with either hematoxylin and eosin or May-Grünwald and Giemsa. The tissues or organs observed included the muscle, digestive tract, hepatopancreas, gill, mantle, heart, and nervous tissue.

Analysis of bacterial 16S rRNA gene (16S rDNA). DNA was extracted from the hemolymph of a diseased abalone according to the general method (Sambrook et al. 1989). 16S rDNA was amplified using universal primers for bacteria, 20F (AGA GTT TGA TCM TGG CTC AG) and 1500R (GGT TAC CTT GTT ACG ACT T) (Weisburg et al. 1991). The nucleotide sequences are based on the International Union of Pure and Applied Chemistry (IUPAC) code. PCR reactions were carried out in $10 \mu \mathrm{l}$ of total volume. The PCR mixture contained 0.25 U Ex Taq HS (Takara), 1× Ex Taq buffer (Takara), $100 \mu \mathrm{M}$ of each dNTP mixture (Takara), 10 pmol of each primer, and about $10 \mathrm{ng}$ extracted DNA. Cycling conditions for PCR were $94^{\circ} \mathrm{C}(30 \mathrm{~s})$, $55^{\circ} \mathrm{C}(30 \mathrm{~s})$, and $72^{\circ} \mathrm{C}(1 \mathrm{~min})$ for 30 cycles (iCycler, BioRad Laboratories). The amplified fragment was purified (QIAquick Gel Extraction Kit, QIAGEN), ligated with the plasmid vector pDrive (QIAGEN PCR Cloning Kit), and applied for nucleotide sequencing (ABI PRISM BigDye Terminator v3.1 Cycle Sequencing Kit, ABI Prism 377 DNA sequencer). The nucleotide sequence of the obtained gene was determined from 20 plasmid clones.

For the identification of the bacterial isolate using $\mathrm{PCR}$, putatively specific primers for the bacterial isolate were designed from the determined 16S rDNA sequence. These were designated as Megai-60 (CGG TAA CAG GAG AAG CTT GCT TCT) and Megai-480r (TCT TTG GGT AAC GTC CTT CTC ATG). A 423 bp fragment was expected to be amplified with these primers. The cycling conditions for the PCR were $94^{\circ} \mathrm{C}$ $(30 \mathrm{~s}), 55^{\circ} \mathrm{C}(30 \mathrm{~s})$, and $72^{\circ} \mathrm{C}(1 \mathrm{~min})$ for 30 cycles. The primers could amplify the target sequence from 2.9 plasmid molecules. DNA extracted from Francisella sp. (Ehime-1, isolated from three-line grunt), F. piscicida (GM2212, isolated from Atlantic cod), and Piscirickettsia salmonis (LF-98) were used for confirmation of the primers' specificity.

Phylogenetic analysis. The 16S rDNA sequences of bacterial species were aligned. A 16S rDNA tree was inferred by the maximum parsimony method. Phylogenetic analyses were carried out using Molecular Evolutionary Genetics Analysis (MEGA) software, version 3.1. For GenBank accession numbers of the sequences used, see Fig. 4.

Bacterial isolation. Frozen hemolymph from diseased abalone was thawed and spread onto modified Eugon agar with hemoglobin $(1 \% \mathrm{w} / \mathrm{v}$, BectonDickinson) dissolved in $70 \%$ seawater and incubated at $15^{\circ} \mathrm{C}$ for $1 \mathrm{wk}$. Seawater was used for adjusting the osmotic pressure of the medium to that of the body fluid of the abalone. To avoid the deposition of hemo- 
globin by the salt in seawater, $4.5 \mathrm{~g}$ Eugon agar (BBL) and $1 \mathrm{~g}$ Hemoglobin powder (Hemoglobin Bovine Freeze-Dried, Becton-Dickinson) were dissolved in 70 $\mathrm{ml}$ artificial seawater (ASW) (New Marine Art, Tomita Pharmaceutical) and $30 \mathrm{ml}$ cold distilled water, respectively, and autoclaved. Seven volumes of the agar solution and 3 volumes of the hemoglobin solution were mixed when the temperatures of the solutions were about 50 to $60^{\circ} \mathrm{C}$, before being poured into Petri dishes. For the preparation of modified Eugon broth supplemented with $\mathrm{FeCl}_{3}$ (2 mM), $3 \mathrm{~g}$ Eugon broth (Becton-Dickinson) was dissolved in $100 \mathrm{ml} 70 \% \mathrm{ASW}$ and autoclaved. Then, filter-sterilized (at $0.22 \mu \mathrm{m}$ ) $1 \mathrm{M}$ $\mathrm{FeCl}_{3}$ solution was added to the broth at room temperature and mixed well until the precipitation was completely dissolved before use.

Growth test for bacterial isolate at different temperatures. One colony of the bacterial isolate was suspended in $500 \mu \mathrm{l}$ PBS. Twenty $\mu \mathrm{l}$ of this suspension was inoculated in each tube containing $20 \mathrm{ml}$ of the modified Eugon broth with $\mathrm{FeCl}_{3}$, and 15 tubes were incubated at different temperatures from 0 to $36^{\circ} \mathrm{C}$ at 2 to $4^{\circ} \mathrm{C}$ intervals $(0,4,6,8,11,14,17,20,22,25,27,29,31$, 34 , and $36^{\circ} \mathrm{C}$ ) for $17 \mathrm{~d}$ in a Temperature Gradient Rocking Incubator (Model TN-3, Toyo Kagaku Sangyo). Bacterial growth was monitored every day by measuring the optical absorbance of the bacterial cultures at $600 \mathrm{~nm}$.

Pathogenicity of bacterial isolate for giant abalone. Healthy giant abalone (shell length: 20 to $30 \mathrm{~mm}$ ) were obtained from Mie Prefectural Science and Technology Promotion Center. The abalone were immediately used for the experiment. The bacterial isolate was cultivated on the modified Eugon agar and incubated at $15^{\circ} \mathrm{C}$ for $5 \mathrm{~d}$, then collected from the agar plate and suspended in ASW. Three groups of healthy giant abalone ( $\mathrm{n}=10$ group $^{-1}$ ) were injected intramuscularly with either $3.2 \times 10^{5}, 3.2 \times 10^{3}$, or $3.2 \times 10^{1} \mathrm{CFU}$ of the bacterial isolate in $0.1 \mathrm{ml}$ ASW for each individual abalone. Another group ( $\mathrm{n}=10$ ) of healthy animals were injected with sterilized ASW as a negative control. Each experimental group was reared at $15^{\circ} \mathrm{C}$ in an acrylic tank $(60 \times 30 \times 36 \mathrm{~cm})$ filled with $57 \mathrm{l}$ running seawater $\left(0.9 \mathrm{l} \mathrm{min}^{-1} \mathrm{tank}^{-1}\right)$ throughout the experimental period. Dissolved oxygen concentration in the rearing seawater, which was filtered through sand, was $7.70 \mathrm{mg} \mathrm{l}^{-1}$ and salinity was 36 at $15^{\circ} \mathrm{C}$. The waste seawater was disinfected with chlorine before draining. Moribund or dead abalone were subjected to isolation of the bacterium from the hemolymph, and stored at $-20^{\circ} \mathrm{C}$. The isolates were checked by PCR using specific primers as described in 'Analysis of bacterial 16S rRNA gene (16S rDNA)'. DNA was extracted from the muscle of the stored abalone from which the bacterium could not be isolated, and the presence of the bacterial gene was checked with PCR. Bacterial isolation was also carried out for the control animals after completion of the experiment, but PCR amplification was not carried out.

Pathogenicity of bacterial isolate at different temperatures and in different animals. Healthy giant abalone (shell length: 20 to $30 \mathrm{~mm}$ ) were obtained as described in 'Pathogenicity of bacterial isolate for giant abalone', and healthy Japanese black abalone Haliotis (Nordotis) discus discus Reeve, 1846 (shell length: 20 to $30 \mathrm{~mm}$ ) were obtained from the Kyoto Institute of Oceanic and Fishery Science. Both abalone species were reared by feeding with dry pelleted food made specifically for abalones (Cosmo Seafarm) and kept at 20 to $25^{\circ} \mathrm{C}$ for about $30 \mathrm{~d}$ until the experiments were carried out. Healthy teleost fish, red sea bream Pagrus major (Temminck et Schlegel, 1844) (average total length: $70 \mathrm{~mm}$ ), were purchased from Kinki University (Wakayama Prefecture, Japan) and reared in the laboratory by feeding with dry pelleted food for Japanese flounder (Higashimaru) and kept for $3 \mathrm{mo}$ at 20 to $25^{\circ} \mathrm{C}$ until the experiments were carried out.

The bacterial isolate was cultivated in the modified Eugon broth $\left(2 \mathrm{mM} \mathrm{FeCl}_{3}\right)$ at $20^{\circ} \mathrm{C}$ for $2 \mathrm{~d}$, then rinsed in ASW and pelleted by centrifugation at $8000 \times g$ for $15 \mathrm{~min}$ at $20^{\circ} \mathrm{C} 3$ times (himac CR22F, Hitachi Koki), and suspended in ASW.

Healthy giant abalone, Japanese black abalone, and red sea bream were injected intramuscularly (abalone) or intraperitoneally (red sea bream) with $5.2 \times 10^{7} \mathrm{CFU}$ of the bacterial isolate in $0.1 \mathrm{ml}$ ASW for each individual, and reared at $15^{\circ} \mathrm{C}$, because the mass mortality of giant abalone had occurred at around $15^{\circ} \mathrm{C}$. Red sea bream was included in the experiment to investigate whether the bacterial isolate was pathogenic to teleost fish. Two more groups of giant abalone were similarly injected and reared at 20 and $25^{\circ} \mathrm{C}$, respectively. Ten animals were used for each group, except the group of giant abalone reared at $25^{\circ} \mathrm{C}$, for which 9 abalone were used. Ten healthy animals were injected with sterilized ASW as the negative control for each species and each rearing temperature. Thus, 10 groups were used in total for this experiment.

Pathogenicity was also tested by immersion infection. Healthy giant abalone, Japanese black abalone, and red sea bream ( $\mathrm{n}=10$ for each species) were immersed in seawater containing $6.9 \times 10^{6} \mathrm{CFU} \mathrm{ml}^{-1}$ of the bacterial isolate for $3 \mathrm{~h}$ at $15^{\circ} \mathrm{C}$. Animals for the negative controls ( $\mathrm{n}=10$ for each species) were similarly immersed in seawater without the bacterial isolate. All groups were reared at $15^{\circ} \mathrm{C}$.

For both experimental infections, each experimental group ( $\mathrm{n}=9$ or 10 group $^{-1}$ ) was reared in the acrylic tank with running seawater as described in 'Patho- 
genicity of bacterial isolate for giant abalone' throughout the experimental period of 3 mo.

Animals were fed dry pelleted food 3 times $\mathrm{wk}^{-1}$. Moribund or dead abalone were subjected to isolation of the bacterium and DNA extraction from the hemolymph or the muscle. For the red sea bream, the kidney was used for DNA extraction and bacterial isolation. The isolates or the extracted DNA were checked by PCR as described in 'Analysis of bacterial 16S rRNA gene (16S rDNA)'. In some dead animals in which the post-mortem deterioration of the tissues was severe, detection of the bacterium was done only by PCR. After completion of the experiments, bacterial isolation and PCR were carried out for all surviving animals including the control animals.

Probes for in situ hybridization. The following 3 antisense oligonucleotide probes were synthesized so that they would hybridize with the 16S rRNA in the cytoplasm. They were complementary to variable regions unique to the sequence of the $16 \mathrm{~S}$ rDNA of the Francisella sp. isolate (see 'Results') in the present study. They were Megai-110r (5'-CCG CCA CTC GTC AGC AAG AAG CAA GCT TCT CCT GTT ACC GTT CGA CTT GC-3'), Megai-230r (5'-CTA ACG CAG GCT CAT CCA TCT GCG GCA GCA CAA AGG CCA CCT TTA ATC CTC AGA TAG TAT-3'), and Megai870r (5'-GAG TAC TTA ACG CGT TAG CTA CGC CAC TAG ATC CTT TAC ACC GAA TCC AAC AGC TAG TAC-3'). For the negative control, a mixture of the following 3 oligonucleotides specific to the $16 \mathrm{~S}$ rRNA of the bacterium Acidovorax sp. were used. They were 5 '-GCA AGG CCT TGC GGT CCC CTG CTT TCA TCC GTA GAT CGT ATG CGG TAT TA-3', 5'TGC CAT CGG CCG CTC CGT CCG CGC AAG GCC TTG CGG TCC CCT GCT TTC ATC CGT AGA TCG3', and 5'-AAG CTT TTA TCC CAC CAA CTA CCT AAT CTG CCA TCG GCC GCT CCG TCC GC-3'. Probes were labelled with digoxigenin, using a commercial kit (DIG Oligonucleotide Tailing Kit, Roche) according to the manufacturer's instructions.

In situ hybridization. From the results of the general histological observation, paraffin-embedded tissue blocks containing many coccus-like particles were selected. Sections were cut at $3 \mu \mathrm{m}$ from these blocks for the in situ hybridization to detect the isolated bacterium. Control tissue sections were also prepared from a tissue block of an abalone in which the coccus-like particles were not observed under ordinary histological observation. This control specimen was one of the giant abalone sent to the NRIA from a public hatchery in the Shimane Prefecture for diagnosis on a different occasion and did not contain any apparent bacteria-like particles in the tissues. It had been fixed and processed similarly to the present samples. In situ hybridization was carried out as follows. Deparaffinized sections were treated with $3 \mu \mathrm{g} \mathrm{ml}^{-1}$ proteinase $\mathrm{K}$ in $20 \mathrm{mM}$ Tris$\mathrm{HCl}$ buffer (pH 8.0) containing $5 \mathrm{mM}$ EDTA, at $37^{\circ} \mathrm{C}$ for $10 \mathrm{~min}$. After rinsing, the sections were incubated with hybridization solution covered with Hybri-Slips (Sigma-Aldrich) in a humid chamber in an incubator at $60^{\circ} \mathrm{C}$ for $2 \mathrm{~h}$. The temperature setting was then changed to $39^{\circ} \mathrm{C}$ without opening the incubator, thus allowing the incubation temperature to lower gradually, and the slides were continually incubated overnight. The hybridization solution contained $21.4 \mathrm{mM}$ Tris- $\mathrm{HCl}(\mathrm{pH} 7.6), 0.5 \mathrm{mg} \mathrm{ml}^{-1}$ sheared salmon sperm DNA (Eppendorf), $80 \mu \mathrm{g} \mathrm{ml}^{-1}$ polyadenylic acid (Roche Diagnostics), $4 \mu \mathrm{g} \mathrm{ml}^{-1}$ poly-deoxy-adenylic acid (Roche), 1.07× Denhardt's solution (Wako Pure Chemical Industries), 10\% dextran sulphate, $1.07 \mathrm{M}$ $\mathrm{NaCl}, 6.4 \mathrm{mM}$ EDTA, and $10 \mathrm{pmol} \mathrm{ml}^{-1}$ labelled probes. The 3 probes for the bacterial isolate and the 3 control probes were used in combination respectively to intensify the hybridization signals. After incubation, the slides were washed in $2 \times \mathrm{SSC}(0.3 \mathrm{M} \mathrm{NaCl}, 30 \mathrm{mM}$ sodium citrate) at $39^{\circ} \mathrm{C}$ for $5 \mathrm{~min}$ twice and in $1 \times \mathrm{SSC}$ at $39^{\circ} \mathrm{C}$ for $5 \mathrm{~min}$ twice. The slides were then rinsed in $100 \mathrm{mM}$ Tris buffer at $\mathrm{pH} 7.5$ containing $0.88 \% \mathrm{NaCl}$, and the signal was detected immunohistochemically with alkaline phosphatase-labelled anti-digoxigenin sheep antibody (Fab fragments, Roche). The final visualization of the signal was performed with 5-bromo-4chloro-3-indolyl phosphate, toluidine salt (BCIP) and nitro blue tetrazolium chloride (NBT), following which the sections were weakly counterstained with Bismarck brown Y.

\section{RESULTS}

\section{Preliminary experiment}

No bacterium that was considered to be a candidate for the causative agent was isolated on brain heart infusion agar, heart infusion agar (containing $2 \%$ $\mathrm{NaCl}$ ), thiosulfate citrate bile saccharose agar, Marine Agar 2216, or Eugon agar with $1 \%$ hemoglobin.

The hemolymph of moribund animals showed pathogenicity for healthy abalone; 9 out of 10 healthy animals injected with the hemolymph died within $12 \mathrm{~d}$. On the other hand, there was no mortality in the abalone injected with PBS or with filtered solution of minced muscle from moribund abalone, suggesting the pathogenic agent did not pass through the $0.45 \mu \mathrm{m}$ pore filter.

\section{Histology}

Many cells were observed in the lumina of gill filaments and in the body cavity of the affected abalone. 
These cells were not observed in the corresponding tissues of healthy abalone. The lumina of gill filaments were often dilated and sometimes filled with clusters of cells (Fig. 1). Numerous spherical, coccus-like particles were observed in 5 of the 6 abalone examined. These bacteria-like particles were about 1 to $2 \mu \mathrm{m}$ in size and most often found in presumptive phagocytes (Fig. 2). Focal lesions were also found in the basal part of the mantle (Fig. 3a). In these lesions, the connective tissue was lost and many coccus-like particles were observed amongst the debris of dead cells (Fig. 3b).

\section{Phylogenetic analysis}

16S rDNA was amplified from a diseased abalone using universal primers. The nucleotide sequence of the obtained gene was determined from 20 plasmid clones (GenBank accession no. AB449247). All the clones were identical and the bacterial isolate was clearly classified as a Francisella sp. (Fig. 4a). The bacterial sequence was not included in the clade of $F$. philomiragia or in fish Francisella spp. isolates, although bootstrap probabilities were low in the cluster (Fig. 4b). Among species of the genus Francisella, the length of the branch to AB449247 was relatively long. AB449247 showed similarities of 97.3 to $97.5 \%$ to the fish Francisella spp. isolates, $97.0 \%$ to F. philomiragia, $95.7 \%$ to $F$. tularensis novicida, and $95.9 \%$ to $F$. tularensis. Principally the same phylogenetic tree was obtained using the neighbor-joining method (data not shown).

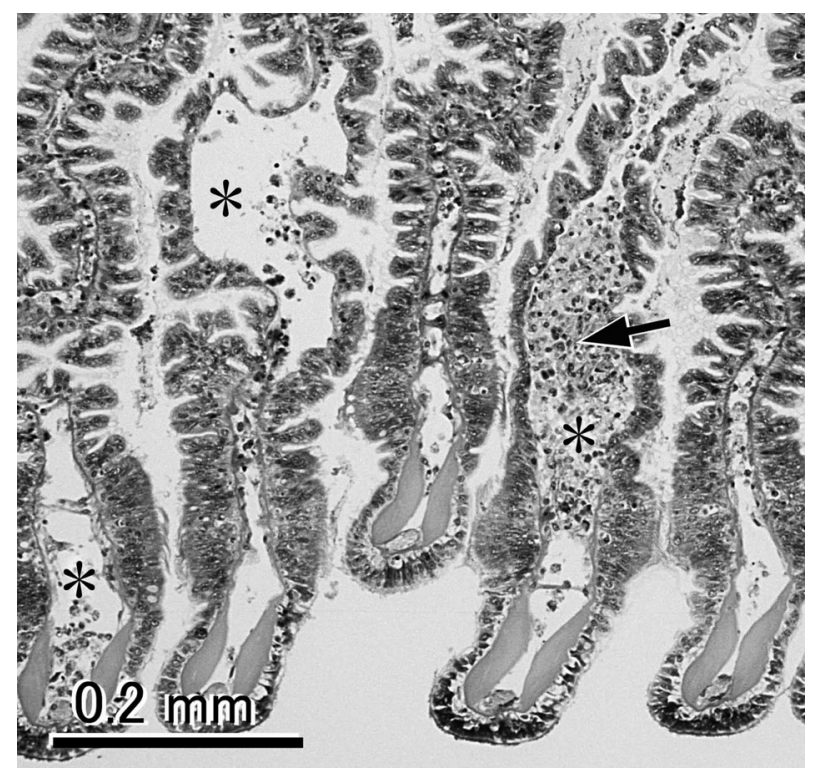

Fig. 1. Haliotis gigantea. Gill filaments of a diseased giant abalone. The lumen of the gill filaments was often dilated (asterisk). Arrow indicates a cluster of cells. May-Grünwald Giemsa stain

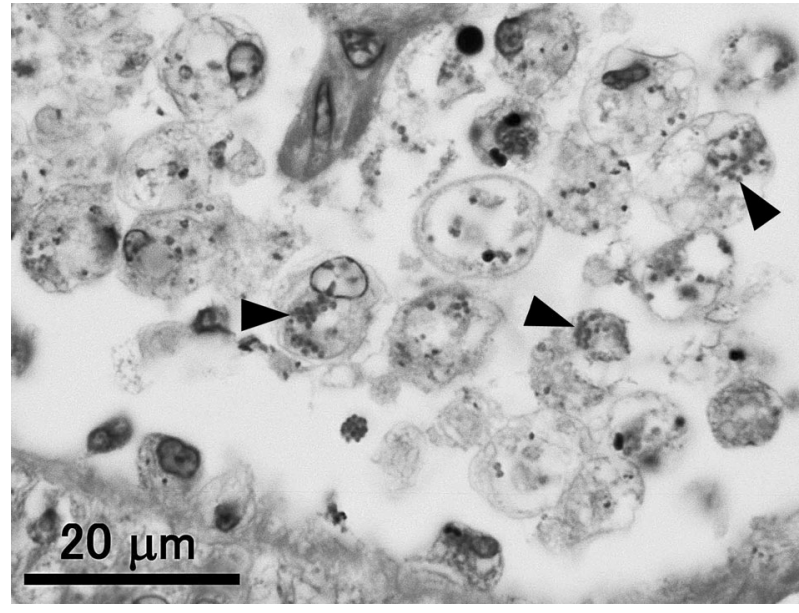

Fig. 2. Haliotis gigantea. Bacteria-like, small spherical particles (arrowheads) in the presumable phagocytes found in a gill filament of a diseased giant abalone. May-Grünwald Giemsa stain

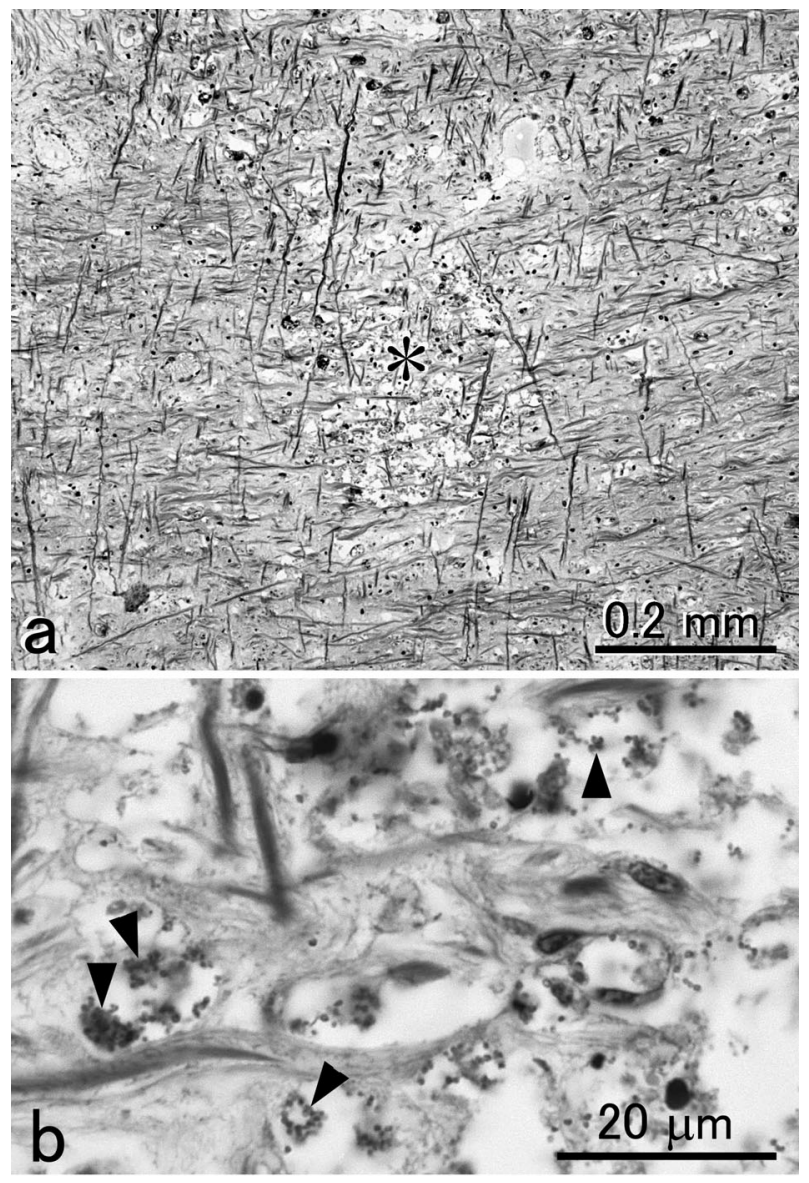

Fig. 3. Haliotis gigantea. (a) A lesion (asterisk) formed in the basal part of the mantle of a diseased giant abalone; the tissue structure was degraded. (b) Part of the lesion shown in (a) at a higher magnification; many bacteria-like particles were observed (arrowheads). May-Grünwald Giemsa stain 


\section{Detection of bacterial 16S rRNA gene (16S rDNA) with PCR}

Using the primer pair designed for the $16 \mathrm{~S}$ rDNA of the Francisella sp. identified from the diseased abalone, a fragment of the expected size (423 bp) was amplified from DNA of the bacterium isolated on the modified Eugon agar. No amplicon was obtained from the templates extracted from Francisella sp. Ehime-1 (isolated from three-line grunt), F. piscicida GM2212 (isolated from Atlantic cod), or Piscirickettsia salmonis LF-98.
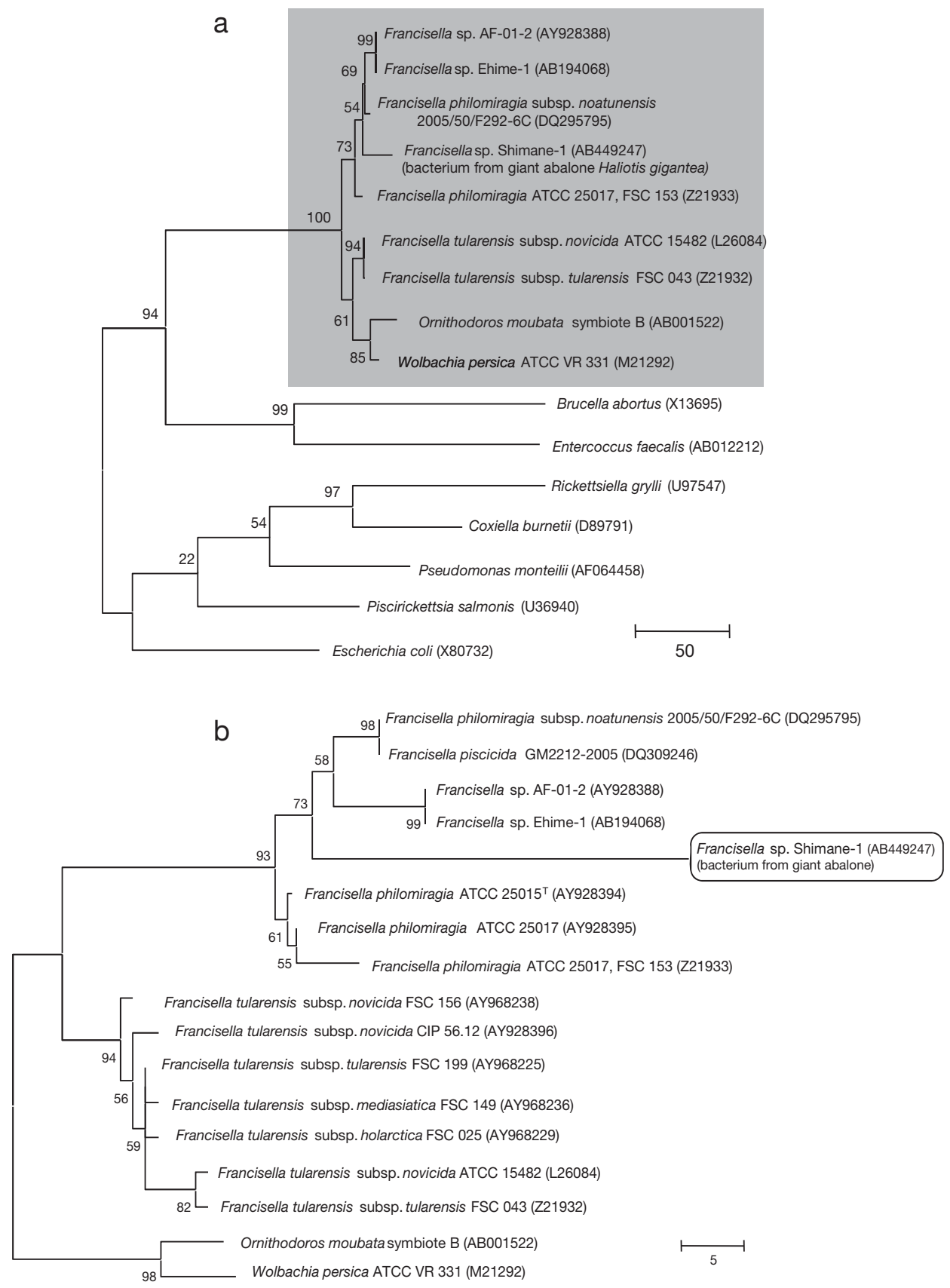

Fig. 4. Phylogenetic relationship of the bacterium isolated from a diseased giant abalone Haliotis gigantea, inferred from the 16S rDNA sequence using the maximum parsimony method. The trees are unrooted. Bootstrap probabilities (\%) that support topological elements are shown on the internal branches. Scale bars indicate estimated sequence divergence. GenBank accession numbers are shown in parentheses. (a) Phylogram of various bacteria including the isolate from the present study; shaded section is shown in more detail in (b). (b) Phylogram of bacteria showing the topology within the genus Francisella 


\section{Isolation and characterization of the bacterium}

After incubating at $15^{\circ} \mathrm{C}$ for $1 \mathrm{wk}$, most of the surface of the modified Eugon agar plate was covered with a colony of a single type. The predominant bacterium was further streaked on a new agar plate. The colonies obtained were white-gray, 1 to $2 \mathrm{~mm}$ in diameter, round and smooth on the agar surface.

The bacterial isolate grew in temperatures ranging from 8 to $25^{\circ} \mathrm{C}$. The best growth was observed from 17 to $22^{\circ} \mathrm{C}$, in which the absorbance of each of these tubes reached a plateau within $6 \mathrm{~d}$ after inoculation.

\section{Pathogenicity of bacterial isolate for giant abalone}

All the giant abalone injected with the bacterial isolate died within 8,12 , and $16 \mathrm{~d}$ dose-dependently, whereas no mortality was observed in the control animals (Fig. 5). From 29 of 30 challenged abalone, a bacterium was isolated and identified by PCR as being the same as the injected bacterium. For the 1 specimen from which the bacterium was not isolated, the bacterial gene was detected by PCR. No bacteria were isolated from the control animals.

\section{Pathogenicity of bacterial isolate at different temper- atures and in different animals}

In both injection and immersion infections, most of the challenged abalone died, whereas no mortality was observed in the abalone treated with only ASW (Fig. 6). No mortality was observed and the bacterial isolate was not detected in the red sea bream irrespective of the challenge methods. The bacterial isolate was detected by PCR in 50 of 59 moribund or dead abalone challenged with infection. The bacterial isolate was re-isolated from 19 of 49 moribund or dead abalone challenged with infection (Table 1). At the end of the experiments, PCR was negative and the bacterium was not isolated in any surviving abalone including control animals.

\section{In situ hybridization}

Strong hybridization signals were observed specifically on the coccus-like particles (Fig. 7) in the sections of diseased giant abalone. No hybridization signal was found in the abalone sections that had no coccus-like particles. A hybridization signal was not observed in the diseased abalone sections when using the probes for Acidovorax sp.

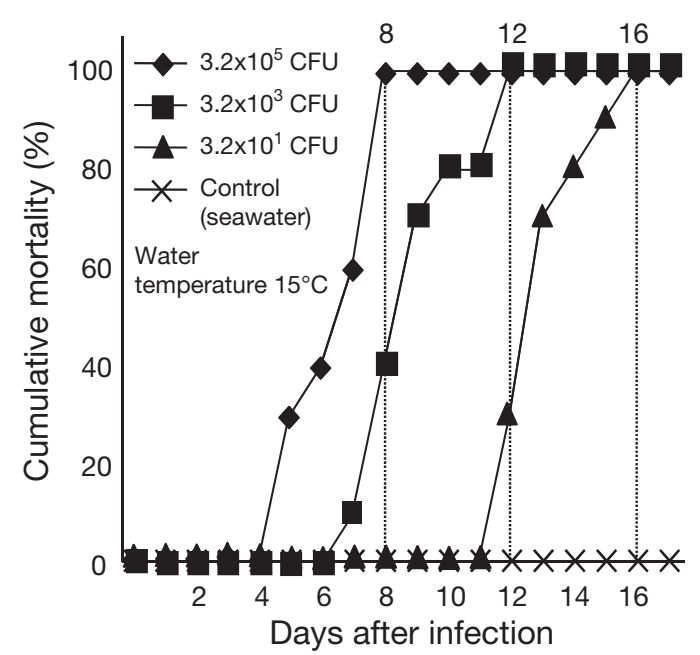

Fig. 5. Haliotis gigantea. Cumulative mortality of giant abalone infected with the cultivated bacterial isolate by intramuscular injection. All the abalone died within $16 \mathrm{~d}$. No mortality was observed in control animals. Moribund abalone sampled for the detection of the bacterial isolate were counted as 'dead'

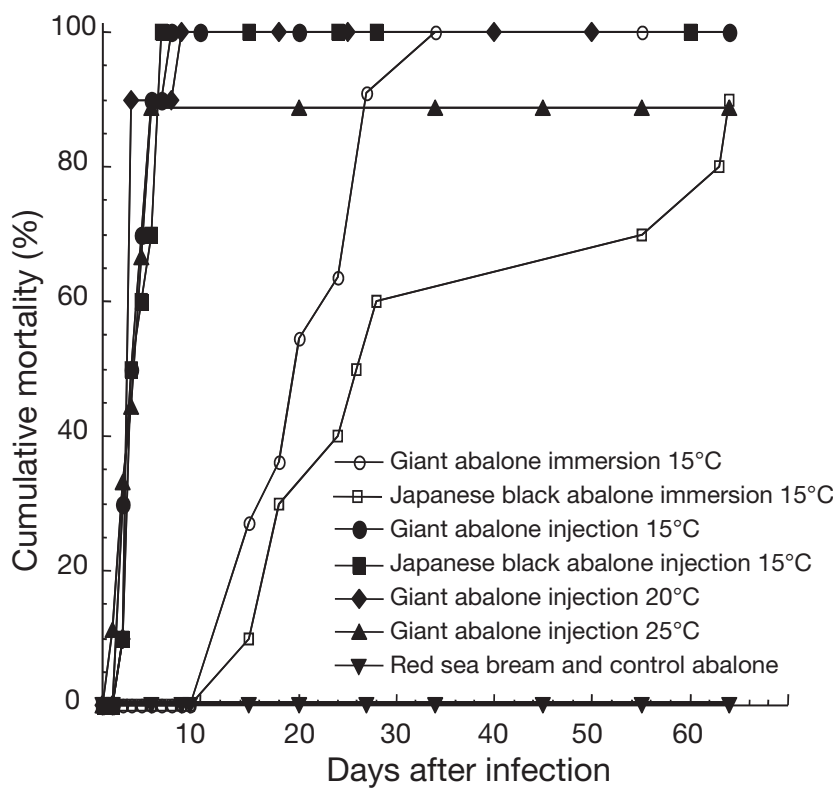

Fig. 6. Haliotis gigantea, H. discus discus, and Pagrus major. Cumulative mortality of abalone and red sea bream infected with the cultivated bacterial isolate by injection or bath immersion. Most of the abalone died within $1 \mathrm{wk}$ after injection. There was almost $100 \%$ mortality of giant abalone at 15,20 , and $25^{\circ} \mathrm{C}(\boldsymbol{\bullet}, \boldsymbol{\Delta})$. All Japanese black abalone at $15^{\circ} \mathrm{C}$ also died (ם). The rises in mortality took about 1 to 2 mo in bath immersion $(O, \square)$. Mortality was not observed in control abalone, which were inoculated with seawater, or in red sea bream irrespective of the bacterial challenge $(\boldsymbol{\nabla})$. Moribund abalone sampled for the detection of the bacterial isolate were counted as 'dead' 


\section{DISCUSSION}

The results of the present study indicate that the mortality of the giant abalone was caused by a bacterium. Analysis of $16 \mathrm{~S}$ rDNA showed that the bacterial isolate belongs to the genus Francisella. This is the first report of Francisella sp. that is pathogenic for a mollusk. Because the 16S rRNA gene is too well conserved to infer the phylogenetic relationships with closely related bacteria, analyses using other appropriate genes, as well as biochemical tests, phenotypic comparisons, and DNA-DNA hybridization with other Francisella spp. are required to clarify the precise phylogenetic position of the present bacterium within the genus Francisella.

Francisella spp. had been previously known only as pathogens of mammals (Wong \& Shapiro 1999, Sjöstedt 2005). In recent years, however, bacteria of this group have also been isolated as pathogens for fishes, such as the isaki (three-line grunt) Parapristipoma trilineatum (Kamaishi et al. 2005), Atlantic cod Gadus morhua (Nylund et al. 2006, Olsen et al. 2006, Mikalsen et al. 2007, Ottem et al. 2007a,b), hybrid striped bass (Ostland et al. 2006), tilapia Oreochromis spp. (Hsieh et al. 2006), Nile tilapia Oreochromis niloticus (Kay et al. 2006, Mauel et al. 2007), ornamental cichlids (Hsieh et al. 2007), and Atlantic salmon Salmo salar (Birkbeck et al. 2007). In addition, some Francisella-like species were detected in environmental samples such as soil and water by PCR-based analyses (Barns et al. 2005). Moreover, F. tularensis can survive and grow in the protozoon Acanthamoeba castellanii (Abd et al. 2003). These reports, together with the results of the present study, suggest that Francisella spp. are not only pathogens for mammals, but also

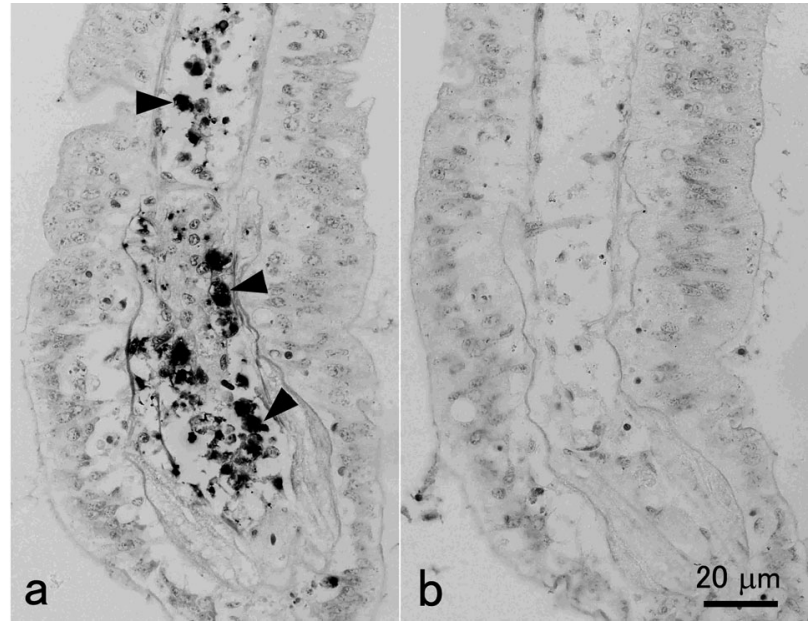

Fig. 7. Haliotis gigantea. In situ hybridization of serial sections from a gill filament of a diseased giant abalone either with (a) the specific probes for the isolated Francisella sp. or (b) control probes. Strong hybridization signals (arrowheads) were observed on the bacteria-like particles when using the specific probes

widely distributed in various natural environments and can be pathogenic for a wide variety of animals.

The bacterium isolated in the present study infects the giant abalone, which is taxonomically very distant from previously reported host animals (vertebrates) for Francisella spp. There were no deaths in red sea bream in the experimental infections in the present study in spite of a relatively high-dose inoculum, whereas the Francisella sp. isolate that was obtained from the three-line grunt Parapristipoma trilineatum was infectious for red sea bream (T. Kamaishi et al. unpubl.). Together with the result that the present bacterial isolate required a higher concentration of salt in

Table 1. Haliotis gigantea, H. discus discus, and Pagrus major. Bacterial culture and PCR results from challenged abalone and sea bream. Actual water temperatures fluctuated within $1^{\circ} \mathrm{C}$ of target water temperatures. No mortality was observed in control animals (data not shown). One severely deteriorated animal was not used for bacterial isolation

\begin{tabular}{|c|c|c|c|c|}
\hline Species & $\begin{array}{l}\text { Target water } \\
\text { temp. }\left({ }^{\circ} \mathrm{C}\right)\end{array}$ & $\begin{array}{l}\text { No. of moribund } \\
\text { or dead animals }\end{array}$ & $\begin{array}{l}\text { PCR-positive } \\
\text { animals (\%) }\end{array}$ & $\begin{array}{c}\text { No. of culture- } \\
\text { positive animals/ } \\
\text { no. of animals examined }\end{array}$ \\
\hline \multicolumn{5}{|l|}{ Challenged with injection } \\
\hline Giant abalone $(\mathrm{n}=10)$ & 15 & 10 & 100 & $3 / 7$ \\
\hline Giant abalone $(\mathrm{n}=10)$ & 20 & 10 & 90 & $2 / 8$ \\
\hline Giant abalone $(\mathrm{n}=9)$ & 25 & 8 & $89^{a}$ & $3 / 8^{\mathrm{a}}$ \\
\hline Black abalone $(\mathrm{n}=10)$ & 15 & 10 & 100 & $5 / 9$ \\
\hline Red sea bream $(n=10)$ & 15 & 0 & 0 & $0 / 10$ \\
\hline \multicolumn{5}{|c|}{ Challenged with immersion } \\
\hline Giant abalone $(\mathrm{n}=10)$ & 15 & 10 & 80 & $3 / 9$ \\
\hline Black abalone $(n=10)$ & 15 & 9 & $50^{\mathrm{a}}$ & $3 / 8^{\mathrm{a}}$ \\
\hline Red sea bream $(n=10)$ & 15 & 0 & 0 & $0 / 10$ \\
\hline
\end{tabular}


the medium to grow, this seems to suggest that the present isolate is not pathogenic to vertebrate fishes, although further challenge tests at different water temperatures are needed to elucidate the pathogenicity of this isolate to fishes.

Although the range of host animals for Francisella spp. is diverse, there seems to be a common mechanism for pathogenesis for this group of bacteria. In mammals, F. tularensis and F. novicida infect and grow in host macrophages (Anthony et al. 1991). Similarly, Francisella spp. reported as fish pathogens seem to be facultative intracellular parasites (Fukuda et al. 2002, Kamaishi et al. 2005, Hsieh et al. 2006, Nylund et al. 2006, Olsen et al. 2006, Ostland et al. 2006, Mauel et al. 2007). In the histological study of affected abalone in the present report, the bacterium was often found in a certain type of cells that were thought to be phagocytes. Therefore, in general, ingestion by host phagocytes seems to be required for Francisella spp. to develop disease in the host animal.

Giant abalone died within 16 d at $15^{\circ} \mathrm{C}$ when inoculated with a low dose of the bacterial isolate of $3.2 \times 10^{1}$ CFU shell ${ }^{-1}$, suggesting high pathogenicity of the isolate for the giant abalone. Results of another experimental infection suggest that the bacterium isolated in the present study can cause disease in Japanese black abalone as well as giant abalone. Indeed, after the identification of the bacterial isolate as the causative agent of the mass mortality in the Shimane Prefecture farm, it was also detected as the presumptive causative agent of disease outbreaks in Japanese black abalone and Yezo abalone Haliotis (Nordotis) discus hannai Ino, 1952 in several public hatcheries (T. Kamaishi et al. unpubl. data). The present Francisella sp. isolate showed best growth in temperatures ranging from 17 to $22^{\circ} \mathrm{C}$, and it caused high mortalities in giant abalone at 15,20 , and $25^{\circ} \mathrm{C}$ in the experimental infections. However, mortality among the abalone associated with the spontaneous infection of the bacterium subsided when water temperature rose above $18^{\circ} \mathrm{C}$. This may be because the biological defense mechanism of the abalone is more active at higher temperatures. In fact, we could not detect the bacterial isolate in the surviving abalone in the experimental infections. This indicates that the abalone has some innate resistance against the bacterium.

Francisella spp. have been frequently identified as fish pathogens. This suggests that this genus might have caused many disease outbreaks in cultured aquatic animals, but has been overlooked because of the lack of histological observations or appropriate culture media for bacterial isolation. Francisella spp. are difficult to culture with ordinary culture media such as ZoBell's 2216 agar or heart infusion agar, which are routinely used for bacterial isolation from aquatic organisms. Therefore, during a disease outbreak in aquatic animals, Francisella spp. should also be considered as a possible cause of the disease, and hence, an appropriate culture medium for these bacteria should be available in the laboratory.

Acknowledgements. This study was financially supported by the Ministry of Agriculture, Forestry and Fisheries of Japan. The authors thank N. Isetani, K. Hayashi, J. Hiraga, and M. Osa for their technical support.

\section{LITERATURE CITED}

Abd H, Johansson T, Golovliov I, Sandströ G, Forsman M (2003) Survival and growth of Francisella tularensis in Acanthamoeba castellanii. Appl Environ Microbiol 69: 600-606

Anthony LD, Burke RD, Nan FE (1991) Growth of Francisella spp. in rodent macrophages. Infect Immun 59:3291-3296

Barns SM, Grow CC, Okinaka RT, Keim P, Kuske CR (2005) Detection of diverse new Francisella-like bacteria in environmental samples. Appl Environ Microbiol 71:5494-5500

Bell TA, Lightner DV (1988) A handbook of normal penaeid shrimp histology. The World Aquaculture Society, Baton Rouge, LA

Birkbeck TH, Bordevik M, Frøystad MK, Baklien A (2007) Identification of Francisella sp. from Atlantic salmon, Salmo salar L., in Chile. J Fish Dis 30:505-507

Fukuda Y, Okamura A, Nishiyama M, Kawakami H, Kamaishi T, Yoshinaga T (2002) Granulomatosis of cultured threeline grunt Parapristipoma trilineatum caused by an intracellular bacterium. Fish Pathol 37:119-124

> Hsieh CY, Tung MC, Tu C, Chang CD, Tsai SS (2006) Enzootics of visceral granulomas associated with Francisella-like organism infection in tilapia (Oreochromis spp.). Aquaculture 254:129-138

Hsieh CY, Wu ZB, Tung MC, Tsai SS (2007) PCR and in situ hybridization for the detection and localization of a new pathogen Francisella-like bacterium (FLB) in ornamental cichlids. Dis Aquat Org 75:29-36

Kamaishi T, Fukuda Y, Nishiyama M, Kawakami H, Matsuyama T, Yoshinaga T, Oseko N (2005) Identification and pathogenicity of intracellular Francisella bacterium in three-line grunt Parapristipoma trilineatum. Fish Pathol 40:67-71

Kay W, Petersen BO, Duus JØ, Perry MB, Vinogradov E (2006) Characterization of the lipopolysaccharide and $\beta$ glucan of the fish pathogen Francisella victoria. FEBS J 273:3002-3013

Mauel MJ, Soto E, Moralis JA, Hawke J (2007) A piscirickettsiosis-like syndrome in cultured Nile tilapia in Latin America with Francisella spp. as the pathogenic agent. J Aquat Anim Health 19:27-34

Mikalsen J, Olsen AB, Tengs T, Colquhoun DJ (2007) Francisella philomiragia subsp. noatunensis subsp. nov., isolated from farmed Atlantic cod (Gadus morhua L.). Int J Syst Evol Microbiol 57:1960-1965

Momoyama K, Nakatsugawa T, Yurano N (1999) Mass mortality of juvenile abalones, Haliotis spp., caused by amyotrophia. Fish Pathol 34:7-14 (in Japanese with English summary)

Nakatsugawa T (1990) Infectious nature of a disease in cultured juvenile abalone with muscular atrophy. Fish Pathol 25:207-211 (in Japanese with English summary) 
Nylund A, Ottem KF, Watanabe K, Karlsbakk E, Krossøy B (2006) Francisella sp. (Family Francisellaceae) causing mortality in Norwegian cod (Gadus morhua) farming. Arch Microbiol 185:383-392

Olsen AB, Mikalsen J, Rode M, Alfjorden A and others (2006) A novel systemic granulomatous inflammatory disease in farmed Atlantic cod, Gadus morhua L., associated with a bacterium belonging to the genus Francisella. J Fish Dis 29:307-311

Ostland VE, Stannard JA, Creek JJ, Hedrick RP, Ferguson HW, Carlberg JM, Westerman ME (2006) Aquatic Francisella-like bacterium associated with mortality of intensively cultured hybrid striped bass Morone chrysops $\times M$. saxatilis. Dis Aquat Org 72:135-145

Ottem KF, Nylund A, Karlsbakk E, Friis-Møller A, Krossøy B (2007a) Characterization of Francisella sp., GM2212, the first Francisella isolate from marine fish, Atlantic cod (Gadus morhua). Arch Microbiol 187:343-350

Ottem KF, Nylund A, Karlsbakk E, Friis-Møller A, Krossøy B,

Editorial responsibility: Eugene Burreson,

Gloucester Point, Virginia, USA
Knappskog D (2007b) New species in the genus Francisella (Gammaproteobacteria; Francisellaceae); Francisella piscicida sp. nov. isolated from cod (Gadus morhua). Arch Microbiol 188:547-550

Sambrook J, Fritsch EF, Maniatis T (1989) Commonly used techniques in molecular cloning. In: Ford N, Natan C, Ferguson M (eds) Molecular cloning, 2nd edn. Cold Spring Harbor Laboratory Press, New York, p E3-E4

Sjöstedt AB (2005) Family III. Francisellaceae fam. nov. In: Brenner DJ, Krieg NR, Staley JT, Garrity GM (eds) Bergey's manual of systematic bacteriology, 2nd edn, Vol 2, part B. Springer, New York, p 199-210

Weisburg WG, Barns SM, Pelletier DA, Lane DJ (1991) 16S ribosomal DNA amplification for phylogenetic study. J Bacteriol 173:697-703

Wong JD, Shapiro DS (1999) Francisella. In: Murray PR, Baron EJ, Pfaller MA, Tenover FC, Yolken RH (eds) Manual of clinical microbiology, 7th edn. American Society for Microbiology, Washington, DC, p 647-651

Submitted: July 31, 2008; Accepted: December 7, 2009

Proofs received from author(s): February 26, 2010 